\title{
BUSINESS DEVELOPMENT STRATEGY OF SHEEP IN CIREBON REGENCY
}

\author{
F. D. Perwitasari", Bastoni, and Bayu Arisandi \\ Universitas Muhammadiyah Cirebon \\ Correspondence Email: caraka20@gmail.com
}

Submitted 01 April 2020; Accepted 14 October 2020

\begin{abstract}
ABSTRAK
Tujuan penelitian ini untuk mengetahui alternatif strategi apa yang dibutuhkan dalam pengembangan usaha ternak domba yang cocok untuk diterapkan di Kabupaten Cirebon, yang diharapkan dapat berimplikasi pada peningkatan produktivitas domba dan kesejahteraan peternak. Lokasi penelitian dilaksanakan di Kabupaten Cirebon, pada bulan Maret sampai bulan Agustus 2018. Metode penelitian adalah metode survei untuk mengumpulkan data primer dari responden dan data sekunder. Pengambilan sampel penelitian ditentukan secara acak sebanyak 43 peternak dari tiga wilayah PUSKESWAN di Kabupaten Cirebon. Analisis data menggunakan analisis lingkungan internal, analisis lingkungan eksternal, dan analisis SWOT. Hasil analisis matriks SWOT berada pada kuadran II dimana tahapan ini dapat Tumbuh dan Dibina. Usaha ini dapat mengalami pertumbuhan dengan baik apabila 1) memperkuat fungsi dan peran kelompok, 2) peternak domba mendapatkan pembinaan dan pedampingan secara terus menerus baik tentang teknis, pengenalan teknologi tepat guna dan pemasaran dari Instansi Pemerintah terutama Dinas Pertanian dan Peternakan, Universitas dan pihak swasta.
\end{abstract}

Kata kunci: analisis SWOT, domba, kelompok tani ternak, strategi pengembangan

\begin{abstract}
The purpose of this study is to find out what alternative strategies are needed in the development of sheep business that are suitable to be applied in Cirebon Regency, which are expected to have implications for increasing sheep productivity and welfare of farmers. The location of the study was carried out in Cirebon Regency, from March to August 2018. The research method was a survey method to collect primary data from respondents and secondary data. The study sample was determined randomly as many as 43 farmers from three PUSKESWAN regions in Cirebon Regency. Data analysis uses internal environment analysis, external environment analysis, and SWOT analysis. The results of the SWOT matrix analysis are in quadrant II where this stage can grow and be fostered. This business can experience good growth if 1) strengthen the function and role of the group, 2) sheep breeders get continuous guidance and guidance both about the technical, introduction of appropriate technology and marketing from Government Agencies, especially the Agriculture and Livestock Services, Universities and private parties.
\end{abstract}

Keywords: development strategy, livestock farming group, sheep, SWOT analysis

\section{INTRODUCTION}

Cirebon Regency is dominated by the development of ruminants with 1000 hectares of land available, especially beef cattle $(3,926$ heads), dairy cows (149 heads), sheep (280,024 heads), goats (14,693 head), buffalo (3,808 heads) (Department of Agriculture,
Livestock and Fisheries of Cirebon Regency, 2017). Meanwhile, for poultry, Cirebon Regency provides 700 hectares of land by providing a feed factory (Comfeed, Sido Agung Prima, JAPFA) and a breading company with a land area of 50 hectares. The sheep population in Cirebon Regency is more than the population of cattle and buffalo. The 
breeders in Cirebon Regency choose sheep for some reasons as follow: 1) feed is easy, 2) it can withstand the temperature in Cirebon Regency that is around $28^{\circ} \mathrm{C}-32^{\circ} \mathrm{C}, 3$ ) Easily maintenance, 4) this business is only for sidejob.

The goat/sheep livestock business still depend on natural resources. Breeders in sheep breeding still use traditional breeding patterns with 3 characteristics, such as limited capital, low input and limited livestock ownership scale between 4 - 6 head of family input (Jaffar and Murdhani, 2020). A livestock production system in various regions has the main problem, such as ensuring the availability of quality forage and land for livestock breeding (Zulfanita, 2011).

Based on this potential, can the sheep business in Cirebon Regency be developed by looking at the constraints and potentials with a SWOT analysis? That is why the aim of the research is to find out what alternative strategies are needed in developing a sheep business that is suitable for implementation in Cirebon Regency. It is expected to have implications for increasing the productivity of sheep and the welfare of breeders.

\section{RESEARCH METHOD}

This research was conducted in Cirebon Regency in March - June 2018. The method of determining the location was purposive sampling. The location selection was chosen deliberately by researchers in livestock farmer groups in Cirebon Regency. The method used in this research was the method of observation. Primary data collection was obtained from the results of interviews with a group of livestock farmers in Cirebon Regency. Samples were taken from 43 members of farmer groups in Cirebon Regency. Secondary data comes from the Cirebon Regency Agriculture office and literature research journals, books, scientific articles. Furthermore, the data collected from the respondents' interviews were analyzed descriptively.
The data analyzed using swot analysis was divided into 2 factors, namely Internal Factor Evolution (IFE) and Excternal Factor Evolution (EFE). Internal environmental analysis (IFE) consists of respondent characteristics, natural resources, maintenance techniques and group dynamics, while external analysis (EFE) includef technology, the role of government and marketing. Furthermore, IFE and EFE were used to analyze the internal and external factors that affected the sheep business development strategy in Cirebon Regency. Furthermore, it was known the strategic position, thus several alternative strategies could be formulated using the SWOT matrix (Strengths, Weaknesses, Opportunities, Threats). From several alternative strategies, one strategy priority could be taken using the Space matrix.

According to Yuniar et al. (2015), space matrix analysis is the difference between internal and external factors used to sharpen the development plan for beef cattle farms in the target area. The results were obtained if the quadrant I (very profitable opportunity), quadrant II (threat), quadrant III (weakness) and Quadrant IV (not profitable).

\section{RESULT AND DISCUSSION}

\section{SWOT Analysis}

SWOT Analysis is strategic planning methods used to evaluate the strengths, weaknesses, opportunities, and threats in a project or business speculation. These four factors formed the SWOT acronym (strengths, weaknesses, opportunities and threats). Data were obtained from in-depth questionnaires to policy holders, breeders, and supporting institutions. In the opinion of Gustina (2012), SWOT analysis is the identification of various factors systematically to formulate a company strategy. This analysis was based on logic that could maximize strengths, opportunities, but simultaneously maximize weaknesses and threats. 
Table 1. Internal Factors Analysis

\begin{tabular}{|c|c|c|c|}
\hline Internal Factors & Weight & Rating & Score \\
\hline \multicolumn{4}{|l|}{ Strength } \\
\hline $\begin{array}{l}1 \text { The seeds are used local seeds which have } \\
\text { good environmental adaptation. }\end{array}$ & 0,15 & 3 & 0,45 \\
\hline $\begin{array}{l}2 \text { Natural resources, especially the availability } \\
\text { of forage and agricultural waste. }\end{array}$ & 0,12 & 3 & 0,36 \\
\hline $\begin{array}{l}3 \text { The availability of supporting facilities and } \\
\text { infrastructure (electricity, roads, and water } \\
\text { sources). }\end{array}$ & 0,15 & 4 & 0,6 \\
\hline 4 The colony stables & 0,08 & 3 & 0,24 \\
\hline Sub Total & 0,5 & & 1,65 \\
\hline \multicolumn{4}{|l|}{ Weakness } \\
\hline 1 Low educational level (SD). & 0,06 & 2 & 0,12 \\
\hline Breeding experience $1-10$ years. & 0,05 & 2 & 0,1 \\
\hline $\begin{array}{l}\text { Limited access to information and } \\
\text { technology. }\end{array}$ & 0,03 & 3 & 0,09 \\
\hline Limited capital. & 0,03 & 4 & 0,12 \\
\hline Breeding cultivation that is still traditional. & 0,08 & 2 & 0,16 \\
\hline Marketing is assisted by collecting traders. & 0,12 & 3 & 0,36 \\
\hline $\begin{array}{l}7 \text { The livestock group is not yet functioning } \\
\text { because the group leader does not want to } \\
\text { share information with his members. }\end{array}$ & 0,02 & 2 & 0,04 \\
\hline $\begin{array}{l}8 \text { There is no regeneration in the organizational } \\
\text { structure. }\end{array}$ & 0,01 & 2 & 0,02 \\
\hline $9 \quad$ Untapped manure. & 0,10 & 3 & 0,3 \\
\hline Sub Total & 0,5 & & 1,31 \\
\hline Total & $\mathbf{1 , 0 0}$ & & 2,96 \\
\hline Difference & & & 0,34 \\
\hline
\end{tabular}

Source: Processed Data, 2018

Analysis results of internal factor were 2.96 consisting of the strength value of 1.65 and the weakness value of 1.31 (Table 1). It means that the strengths possessed by the respondents exceeded the existing weaknesses, thus the sheep live-stock/farming business can be developed by using the maximum possible strength. While the results of the analysis of external factors of 3.62 consists of an opportunity value of 2.17 and a threat value of 1.45 (can be seen in Table 2), it tried to maximize as possible in exploiting opportunities and trying to reduce threats, namely by means of utilize and optimize existing natural resources by utilizing local materials as a source of animal feed, especially agricultural waste, feed processing technology, manure processing technology and using local seeds that have good environmental adaptation.

This was also supported by the results of research by Adinata et al. (2012), it stated that the main alternative strategy can be applied in developing a beef cattle business by optimizing and developing internal breeders' capabilities, utilizing available natural resources to increase the scale of beef cattle business to more advanced, the 
Table 2. Efficiency Scale and Return to Scale from DEA

\begin{tabular}{|c|c|c|c|}
\hline Eksternal Factors & Weight & Rating & Score \\
\hline \multicolumn{4}{|l|}{ Opportunities } \\
\hline 1. Ownership status of own business. & 0,11 & 3 & 0,33 \\
\hline 2. Broad marketing area in Ciayumajakuning & 0,15 & 4 & 0,6 \\
\hline 3. The demand for lamb is increasing. & 0,16 & 4 & 0,64 \\
\hline $\begin{array}{l}\text { 4. Support from Local Government of Cirebon } \\
\text { Regency. }\end{array}$ & 0,15 & 4 & 0,6 \\
\hline Sub Total & $\mathbf{0 , 5 7}$ & & 2,17 \\
\hline \multicolumn{4}{|l|}{ Threats } \\
\hline $\begin{array}{l}\text { 1. The younger generation is not interested in } \\
\text { becoming breeders. }\end{array}$ & 0,07 & 3 & 0,21 \\
\hline $\begin{array}{l}\text { 2. Complicated procedures for borrowing business } \\
\text { capital. }\end{array}$ & 0,05 & 2 & 0,1 \\
\hline 3. The low selling price of livestock. & 0,11 & 4 & 0,44 \\
\hline $\begin{array}{l}\text { 4. Feed processing technology, especially } \\
\text { concentrate feed has not been provided as } \\
\text { additional feed for livestock. }\end{array}$ & 0,10 & 4 & 0,4 \\
\hline $\begin{array}{l}\text { 5. Livestock manure processing technology has } \\
\text { not been implemented so that it can have an } \\
\text { impact on environmental pollution }\end{array}$ & 0,10 & 3 & 0,3 \\
\hline Sub Total & $\mathbf{0 , 4 3}$ & & 1,45 \\
\hline Total & 1 & & 3,62 \\
\hline Difference & & & $\mathbf{0 , 7 2}$ \\
\hline
\end{tabular}

Source: Processed Data, 2018

introduction of agricultural waste-based feed processing technology and superior cattle breeds adapted to local conditions, establishing partnerships with the government and third parties.

\section{Matrix Analysis of Internal Factor Evaluation}

According to Putritamara et al. (2017), Matrix of internal factor evaluation (IFE) and Matrix Eksternal Factor Evaluation (EFE) are used to evaluate internal environmental factors (strengths and weaknesses) and external environment (opportunities and threats). The score results obtained from this matrix analysis show the company's ability to take advantage of existing strengths and overcome weaknesses, demonstrate the ability to gain opportunities and overcome external threats.

This analysis was to find out how to determine the position of the quadrant matrix position for the sheep group in Cirebon Regency and determine the best strategy that had to be applied in the development of sheep farming businesses. Based on the results of the analysis on the IFAS and EFAS matrices, the results of the weighted score for the SWOT quadrant matrix are:

1. Total score of internal strength 1.65

2. Total score of internal weakness 1.31

3. Total external opportunity score 2.71

4. Total external opportunity score 1.45

This calculation result could shoe the position of the quadrant matrix for the sheep, namely 1) internal factors (strengths and weaknesses) as determinants of the $\mathrm{x}$-axis 


\begin{tabular}{|c|c|c|c|}
\hline IFAS and EFAS & High score $(3,0-4,0)$ & $\begin{array}{c}\text { Medium score } \\
(2,0-2,99)\end{array}$ & Low score $(0,1-1,99)$ \\
\hline $\begin{array}{l}\text { High score } \\
(3,0-4,0)\end{array}$ & $\begin{array}{l}\text { Quadrant I } \\
\text { Concentration } \\
\text { through Vertical } \\
\text { Integration }\end{array}$ & $\begin{array}{l}\text { Quadrant II } \\
\text { IEF and EFF(2.92 \& } \\
\text { 3,62) } \\
\text { Grow and be nurtured } \\
\text { Concentration through } \\
\text { horizontal integration }\end{array}$ & $\begin{array}{l}\text { Quadrant III } \\
\text { Turn around }\end{array}$ \\
\hline $\begin{array}{l}\text { Medium score } \\
(2,0-2,99)\end{array}$ & $\begin{array}{l}\text { Quadrant IV } \\
\text { Stability }\end{array}$ & $\begin{array}{l}\text { Quadrant V } \\
\text { Concentration through } \\
\text { horizontal integration }\end{array}$ & $\begin{array}{l}\text { Quadrant VI } \\
\text { Divesrment strategy }\end{array}$ \\
\hline $\begin{array}{l}\text { Low score } \\
(0,1-1,99)\end{array}$ & $\begin{array}{l}\text { Quadrant VII } \\
\text { Diversification } \\
\text { Concenteric }\end{array}$ & $\begin{array}{l}\text { Quadrant VIII } \\
\text { Diversification } \\
\text { Conglomerate }\end{array}$ & $\begin{array}{l}\text { Quadrant IX } \\
\text { Liquidity }\end{array}$ \\
\hline
\end{tabular}

Source: Processed Data, 2018

point, 2) external factors (opportunities and threats) are used as determinants of the y-axis point. The results of the calculations are:

1. Point $x$ axis: $1.65+1.31=2.96$

2. Y-axis point: $2.17+1.45=3.62$

The quadrant matrix of the Sheep SWOT analysis was mapped to quadrant II (Table 3). The results of the mapping of the total score for the development of the sheep husbandry business were in quadrant II. This situation was profitable for the group because in Quadrant II, this stage can be grown and fostered. This business can experience good growth if 1) it strengthend the function and role of the group, 2) sheep breeders obtained guidance and assistance both on technical matters, the introduction of appropriate technology and marketing from Government Agencies, especially the Department of Agriculture and Animal Husbandry, Universities and the private sector .

This was supported by the results of research by Yuniar et al. (2015), that was specifically for the development of beef cattle farms in South Tangerang City, the strategic priority that would be applied was the ST strategy (quadrant II). Guidance from related agencies regarding the use of waste processing technology was needed for breeders to address the issue of environmental pollution caused by livestock waste. The
Department of Agriculture and Food Security of South Tangerang City and the Regional Environmental Agency of South Tangerang City in this case could play a bigger role in fostering breeders regarding waste management. Meanwhile, according to Prayudha et al. (2014), quadrant II shows that the region is facing various threats, but still has strength so that the strategy adopted was to use strength to take advantage of long-term opportunities by implementing a diversification strategy. Therefore, the results of the space analysis confirm the results of the external internal matrix analysis.

\section{Alternative Strategy of Sheep Livestock Business Development in Cirebon Regency}

The identification process is internal and external factor. Thus, it will obtain strengths, weaknesses, as well as opportunities and threats in the development of the sheep business in Cirebon Regency. The formulation of alternative development strategies was considered based on the identification of internal and external factors, as well as influential and homogeneous in the research location. The combination and combination of internal and external factors will provide several alternative strategies that can be applied in the development of the sheep business in Cirebon Regency, that are listed in the SWOT matrix in Table 4. 
Table 4. SWOT Analysis Matrix

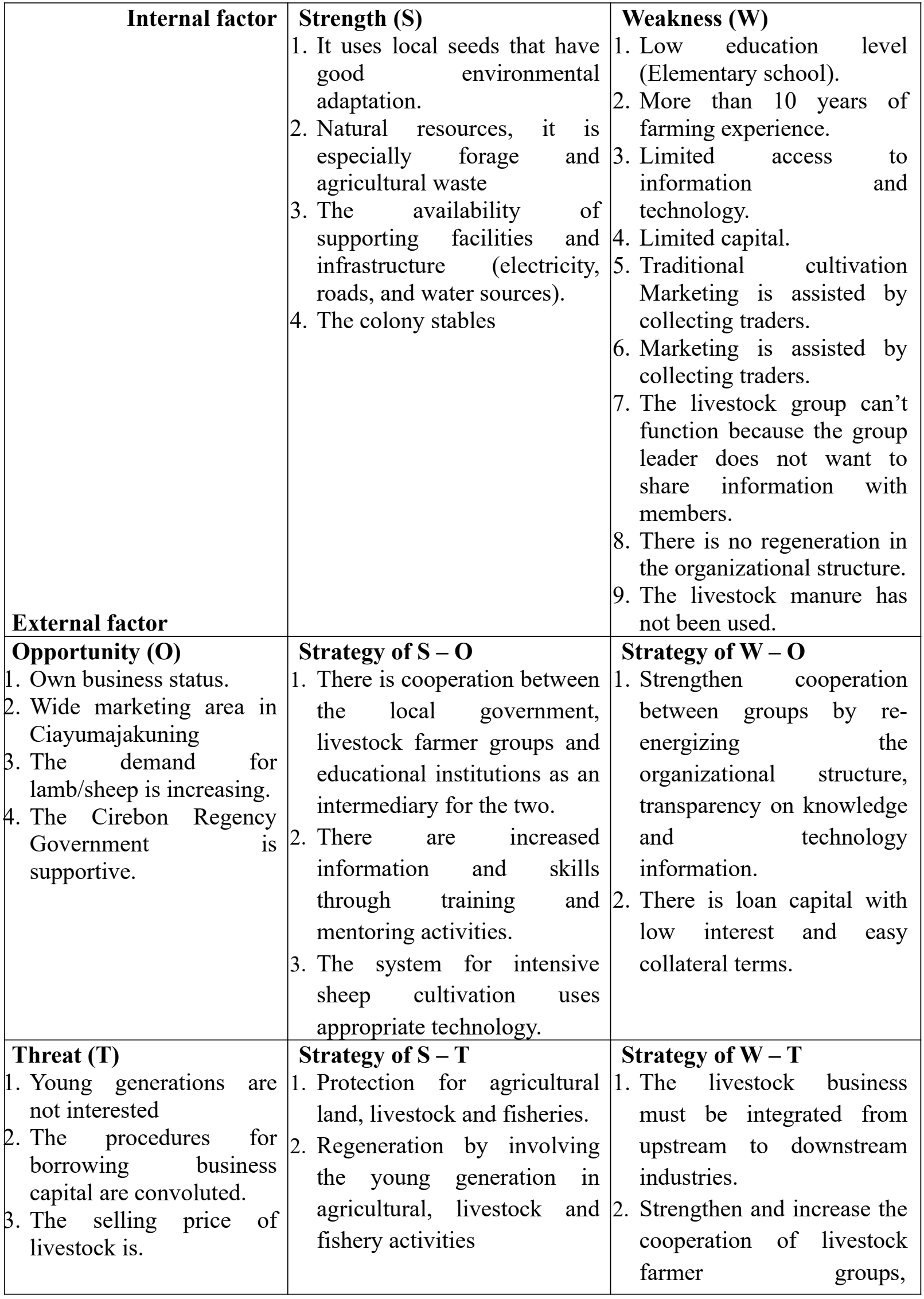




\begin{tabular}{|c|c|c|}
\hline $\begin{array}{l}\text { 4. The concentrate feed has } \\
\text { not been provided as } \\
\text { additional feed for } \\
\text { livestock. } \\
\text { 5. The Impact of } \\
\text { environmental pollution }\end{array}$ & $\begin{array}{l}\text { 3. Introducing additional types } \\
\text { of feed to the farmer }\end{array}$ & $\begin{array}{lr}\text { thus breeders have } \\
\text { different positions in } \\
\text { determining prices }\end{array}$ \\
\hline
\end{tabular}

Source: Processed Data, 2018

In detail, there were four types of alternative strategies that could be applied in developing a sheep business in Cirebon Regency, as follow:

\section{The Strategy of SO (Strength-Opportunity)}

SO strategy uses internal strength to be able to take advantage of external opportunities. Alternative SO strategies can be formulated as follows:

1. It strengthens cooperation between groups by re-energizing the organizational structure, transparency on knowledge and technology information. With increased cooperation between groups, members can openly convey information about knowledge and technology. There is a regeneration in the organizational structure so that the livestock group can run as it should.

2. There is loan capital with low interest and easy collateral terms.

\section{The Strategy of S-T (Strenght-Threat)}

ST strategy is to be able to optimize internal strength possessed in avoiding threats. Alternative ST strategies that can be formulated include:

1. Protection for agricultural land, livestock and fisheries.

2. Regeneration by involving the young generation in agricultural, livestock and fishery activities.

3. Introducing additional types of feed to the farmer.

It is in line with the opinion of Adinata et al. (2012) that ST strategy is to develop human resource skills and improve efficiency patterns in order to master and increase productivity in the livestock business sector; establishing partnerships with the government and third parties by utilizing the interaction of rural communities that are kinship and mutual cooperation.

\section{The Strategy of W-T (Weakness - Threat)}

WT strategy is defensive strategy to minimize internal weakness and avoid external threats. Alternative strategies that can be formulated include:

1. The livestock business must be integrated from upstream to downstream industries.

2. It strengthens and increases the cooperation of livestock farmer groups so that breeders have different positions in determining prices.

It is in line with the argumentation of Kasworo et al. (2013) that alternative strategies that can be formulated include strengthening farmer institutions so that breeders have a strong bargaining power through ongoing mentoring and counseling regarding cultivation, partnerships and livestock business agreements. The strategic objectives from the explanation above can be concluded that for the development of the sheep business in Cirebon Regency, the steps needed to achieve these goals are:

1. Improvements to livestock farmer groups are a) it needs to re-organize organizational structures by involving members of livestock farmer groups who are still in productive age, b) it needs division of organizational structures according to duties and obligations, c) openness and transparency of all information.

2. There needs re-regeneration of breeders by involving livestock farmer groups with youth groups in the livestock sector

3. It needs protection of agricultural land, so that the places are not displaced by human 
settlements and idle lands are used for forage.

4. There is involvement and good cooperation in service and research activities, such as government agencies (Agricultural Service), Animal Farmers Group and Educational Institutions (Universitas Muhammadiyah Cirebon).

\section{CONCLUSION}

The results of the research can be concluded that Alternative Sheep Livestock Business Development Strategies in Cirebon Regency are a) improving the organizational structure within livestock farmer groups, b) It needs to be re-regeneration of breeders by involving livestock farmer groups with youth groups in the field of animal husbandry, c) It needs protection of agricultural and live-stock lands, so that unused lands can be utilized. d) There is good cooperation between government agencies (Dinas Pertanian), Animal Farmers Groups and Educational Institutions (Universitas Muhammadiyah Cirebon). The government, society, educational institutions (universities) can take full advantage of the existing potential. Thus, the management of the sheep business can be maximized. If it can not be maximized, it will be useless and unhelpful in efforts to improve the welfare of breeders.

\section{REFERENCES}

Adinata K. I., A. I. Sari, and E. T. Rahayu. 2012. Strategi pengembangan usaha sapi potong di Kecamatan Mojolaban Kabupaten Sukoharjo. Tropical Animal Husbandry 1(1): 24-32.

Badar, G. A, S. Rahayu, and S. Kuswanyan. 2015. Faktor teknis, sosial dan ekonomi yang mempengaruhi penerimaan usaha ternak domba yang di gembalakan. Students E-Journal 4(1): 1-14.

Department of Agriculture, Livestock and Fisheries of Cirebon Regency. 2017.
Populasi ternak Kabupaten Cirebon. Dinas Pertanian Peternakan dan Perikanan: Kabupaten Cirebon.

Gustina, S. 2012. Analisis kelayakan dan strategi pengembangan usaha ternak sapi potong. Jurnal Agrium 17(3): 192201.

Jaffar, M. and K. Murdhani. 2020. Analisis ekonomi penggemukan kambing kacang berbasis sumber daya lokal. Jurnal Real Riset 2(3): 145-152.

Kasworo, B. A, M. Izzati and Kismartini. 2013. Pengelolaan penggemukan sapi potong yang berkelanjutan di Desa Jogonayan Kecamatan Ngablak Kabupaten Magelang. Thesis. Program Pascasarjana Magister Ilmu Lingkungan, Universitas Diponegoro, Semarang.

Putritamara, J. A., N. Febrianto, and P. H. Ndaru. 2017. Strategi pemasaran sapi potong di PT. Tunas Jaya Raya Abadi Nganjuk. Jurnal Ilmu-Ilmu Peternakan 28(2): 96-104.

Prayudha, E. D., B. Soelardiono, and B. Hendrarto. 2014. Strategi kelompok pantai lestari dalam pengembangan rehabilitasi mangrove di Desa Karangsong, Kabupaten Indramayu. Management of Aquatic Resources Journal 3(3): 80-87.

Yuniar P. S., Widiatmaka, and A. M. Fuah. 2015. Analisis potensi pengembangan peternakan sapi potong di Kota Tangerang Selatan. Jurnal Ilmu Produksi dan Teknologi Hasil Peternakan 3(2): 106-112.

Zulfanita. 2011. Kajian analisisa usaha ternak kambing di Desa Lubangsampang Kecamatan Pituruh Kabupaten Purworejo. Mediaagro 7(2): 61-68. 